\title{
PENGARUH UKURAN PERUSAHAAN KLIEN DAN ROTASI AUDIT TERHADAP KUALITAS AUDIT PADA PERUSAHAAN MANUFAKTUR YANG TERDAFTAR DI BURSA EFEK INDONESIA TAHUN 2012-2015
}

\author{
Andreas Berikang ${ }^{1}$, Lintje Kalangi ${ }^{2}$, Heince Wokas ${ }^{3}$ \\ ${ }^{1,2,3}$ Fakultas Ekonomi dan Bisnis, Jurusan Akuntansi, Universitas Sam Ratulangi, Jl.Kampus Bahu, Manado, \\ 95115, Indonesia \\ E-mail : augieberikang71@gmail.com
}

\begin{abstract}
The quality of an audit report on a financial statement is very important for shareholders or other third parties in making decisions. The purpose of this study is to examine the effect of client firm size and audit rotation of audit quality. Audit quality uses proxies public accounting firm size, which is measured by dummy variables using the Big Four public accounting firm and Non Big four public accounting firm, the size of the client firm was measured by calculating the natural logarithm of the firm's total assets, audit rotation was measured by dummy variable. Population in this research is manufacturing firm listed in Indonesia Stock Exchange from 2012-2015, sampling method used in this research use purposive sampling method. This research is using the logistic regression analysis using SPSS 22 version. The result indicates that: (1) firm client size has significant effect towards audit quality, (2) audit rotation has no effect towards audit quality.
\end{abstract}

Keywords: Audit Quality, Client Company Size, Audit Rotation, Auditor.

\section{PENDAHULUAN}

Kegiatan operasional perusahaan dan posisi keuangan sebuah perusahaan wajib dilaporkan oleh manajemen lewat laporan keuangan. Namun dalam pelaporan keuangan muncul kemungkinan terjadinya perbedaan kepentingan antara manajemen dengan pemakai laporan keuangan karena timbulnya kesenjangan informasi yang disediakan. Untuk menilai keandalan laporan keuangan diperlukan peran pihak ketiga yang indpenden dan kompeten dengan menunjuk akuntan publik.

Jasa akuntan publik menyediakan jasa audit keuangan yang digunakan oleh pihak luar perusahaan seperti calon investor, investor, dan pihak lain yang terkait untuk menilai perusahaan atau badan hukum lainnya (termasuk pemerintah) untuk menghasilkan pendapat atau opini tentang laporan keuangan yang relevan, akurat, lengkap, dan disajikan secara wajar. Para pengguna laporan keuangan mengaharapkan bahwa laporan keuangan yang telah diaudit oleh auditor eksternal bebas dari salah saji material, dapat dipercaya kebenarannya untuk dijadikan sebagai dasar pengambilan keputusan dan telah sesuai dengan prinsip-prinsip akuntansi yang berlaku di Indonesia, Maharani (2014).

Persaingan dalam dunia modern semakin ketat, begitu juga dengan persaingan dalam bisnis pelayanan jasa akuntan publik. Agar dapat bertahan dalam persaingan pelayanan jasa akuntan publik dituntut untuk dapat menghimpun klien sebanyak mungkin dan mendapat kepercayaan yang luas dari masyarakat, oleh karena para auditor dituntut untuk tetap memiliki kualitas audit yang baik. Banyak perusahaan yang sudah go public terdorong untuk memakai jasa pelayanan publik yang memiliki hasil audit yang berkualitas, dimana semakin sering kantor pelayanan jasa akuntan publik dipercaya untuk mengaudit laporan keuangan perusahaan maka semakin tinggi reputasi kantor akuntan publik yang beredar di masyarakat umum, Kurniasih (2014). 
Di Indonesia kasus tentang kualitas audit oleh Kantor Akuntan Publik antara lain kasus PT Inovisi Infracom Tbk (INVS) mendapat sanksi penghentian sementara (suspen) perdagangan saham oleh PT Bursa Efek Indonesia (BEI). Sanksi ini diberikan karena ditemukan banyak kesalahan di laporan kinerja keuangan perusahaan kuartal III-2014. Perseroan pun menunjuk kantor akuntan publik (KAP) yang baru untuk melakukan audit terhadap laporan keuangan perusahaan tahun buku 2014. Perusahaan investasi tersebut menunjuk Kreston International (Hendrawinata, Eddy Siddharta, Tanzil, dan rekan) untuk mengaudit laporan kinerja keuangannya. Sebelumnya PT Inovisi memakai KAP Jamaludin, Ardi, Sukimto, dan rekan pada audit laporan keuangan 2013.

Kecurangan laporan keuangan yang melibatkan kantor akuntan publik peringkat teratas ini mendorong Kongres Amerika Serikat untuk mengesahkan Sarbanes - Oxley Act pada tahun 2002 yang merupakan awal reformasi atas profesi akuntansi publik, tidak saja di Amerika Serikat melainkan juga di negara - negara lain. Dalam peraturan tersebut diatur terkait beberapa peraturan yang mengatur kebijakan akuntan publik baik kantor akuntan public maupun partner audit. Dalam Sarbanes - Oxley Act diatur pada sesi 203, terkait partner audit yang dibatasi penugasan auditnya paling lama lima tahun buku berturut - turut, Athoi (2015).

Peraturan terkait rotasi audit dalam Sarbanes - Oxley Act selanjutnya digunakan dan diadopsi oleh beberapa Negara lain termasuk Indonesia. Rotasi audit di Indonesia bersifat mandatory, diatur dalam Keputusan Menteri Keuangan nomor: 17/KMK.01/2008 tentang "Jasa Akuntan Publik" pasal 3. Peraturan tersebut mengatur tentang pemberian jasa audit umum atas laporan keuangan dari suatu entitas dilakukan oleh Kantor Akuntan Publik paling lama untuk 6 (enam) tahun buku berturut-turut dan oleh seorang Akuntan Publik paling lama 3 (tiga) tahun buku berturut-turut (Keputusan Menteri Keuangan Republik Indonesia 2008).

Fernando, Ahmed, dan Randal (2010) menyatakan bahwa kualitas audit juga dikaitkan dengan ukuran perusahaan dan ukuran KAP. Perusahaan berukuran kecil cenderung memiliki informasi dan sistem pengendalian internal yang lemah, sehingga menghasilkan audit yang lebih berkualitas. Di sisi lain, semakin besar ukuran perusahaan, maka semakin meningkat pula agency cost yang terjadi. Oleh karena itu, perusahaan berukuran besar akan cenderung memilih jasa auditor yang profesional dan independen untuk menghasilkan kualitas audit yang tinggi .

Becker, DeFond, Jiambalvo dan Subrayamanyam (1998) menemukan bahwa KAP Big Four cenderung memiliki tingkat kualitas audit yang lebih tinggi dibanding dengan KAP non-Big Four. Independensi auditor besar lebih terjaga karena rendahnya pengaruh ketergantungan ekonomi auditor terhadap klien, dan auditor besar berpeluang mengalami kerugian lebih besar pada kasus kegagalan audit, bila dibandingkan dengan auditor kecil sehingga jaminan atas kualitas audit harus lebih ditingkatkan.

\section{TINJAUAN PUSTAKA}

\subsection{Ukuran Perusahaan Klien}

Perusahaan kecil memiliki lingkup informasi yang lebih sedikit dibandingkan dengan perusahaan. Perusahaan yang lebih besar memiliki analisis yang lebih tinggi dan persentase kepemilikan institusional yang lebih tinggi. Selain itu, perhatian yang lebih besar oleh media ditujukan pada perusahaan besar sehingga perusahaan yang lebih kecil kurang diperhatikan oleh pemegang sahamnya dimana hal tersebut menandakan kurangnya informasi dan pengawasan yang lemah. Keadaan tersebut sangat kondusif untuk lebih memperlihatkan pengaruh peran informasi dan pengawasan audit. Oleh karena itu, dampak dari kualitas audit yang lebih tinggi akan lebih besar bagi perusahaan-perusahaan kecil, sedangkan bagi perusahaan besar peningkatan kualitas audit tidak begitu berpengaruh karena mereka 
memiliki kualitas pengendalian yang lebih baik dibandingkan perusahaan kecil Fernando, et al (2010).

\subsection{Rotasi Audit}

Dengan adanya kasus Enron yang melibatkan kantor akuntan publik (KAP) internasional Arthur Anderson (AA) maka di Indonesia dilakukan peraturan tindakan pergantian auditor secara wajib. Penerapan ketentuan tentang adanya rotasi mandatory ini dengan tujuan supaya dapat meningkatkan independensi auditor baik secara tampilan maupun secara fakta. Rotasi mandatory ini diharapkan dapat berpengaruh signifikan pada praktik pengauditan yang dilakukan oleh seorang auditor dengan menjaga sikap independensi (Giri, 2010).

Peraturan Pemerintah tentang adanya rotasi mandatory di Indonesia sesuai dengan Keputusan Menteri Keuangan No.423/KMK.06/2002 menyatakan, pemberian jasa audit umum atas laporan keuangan dari suatu entitas dapat dilakukan oleh KAP paling lama untuk 5 (lima) tahun buku berturut-turut dan oleh seorang Akuntan Publik paling lama untuk 3 (tiga) tahun buku berturut-turut. Kemudian peraturan tersebut di revisi dengan KMK No.359/KMK.06/2003 dan direvisi kembali KMK No.17/KMK.01/2008 tentang Jasa Akuntan Publik menyatakan pemberian jasa audit umum atas laporan keuangan dari suatu entitas dapat dilakukan oleh KAP paling lama untuk 6 (enam) tahun buku berturut-turut dan oleh seorang Akuntan Publik paling lama untuk 3 (tiga) tahun buku berturut-turut.

\subsection{Kualitas Audit}

Menurut Hartadi (2012) bahwa kualitas merupakan profesionalisme kerja yang harus benar-benar dipertahankan oleh akuntan publik profesional. Independen sangat penting dimiliki oleh auditor dalam menjaga kualitas audit dimana akuntan publik lebih mengutamakan kepentingan publik diatas kepentingan manajemen atau kepentingan auditor sendiri dalam membuat laporan auditan. Hasil audit yang berkualitas dapat mempengaruhi citra dari Kantor Akuntan Publik sendiri, dimana kualitas audit yang mengandung kejelasan informasi dari hasil pemeriksaan yang dilakukan oleh auditor atas laporan keuangan yang diaudit sesuai dengan standar auditing.

\subsection{Pengaruh Ukuran Perusahaan Klien terhadap Kualitas Audit.}

Ukuran perusahaan dapat mempengaruhi kualitas audit. Perusahaan berukuran besar karena kompleksitas operasi dan peningkatan pemisahan antara manajemen dan pemegang saham, sangat memerlukan KAP yang dapat mengurangi agency cost. Selain itu, jumlah konflik agensi yang meningkat menyebabkan permintaan untuk membedakan kualitas auditor juga meningkat. Oleh karena itu, perusahaan berukuran besar pastinya akan lebih memilih menggunakan jasa KAP berukuran besar untuk menghasilkan laporan audit yang berkualitas.

Penelitian yang dilakukan Sinaga (2014) membuktikan bahwa variabel ukuran perusahaan klien berpengaruh secara signifikan terhadap kualitas audit. Penelitian yang dilakukan oleh Febriyanti (2014) menunjukan bahwa variabel ukuran perusahaan klien berpengaruh positif dan signifikan terhadap kualitas audit.

Berdasarkan uraian tersebut maka dirumuskan hipotesis pertama :

$\mathrm{H}_{1}$ : Ukuran perusahaan klien berpengaruh terhadap kualitas audit.

\subsection{Pengaruh Rotasi Audit terhadap Kualitas Audit.}

Hubungan yang ada antara rotasi audit dengan kualitas audit adalah rotasi audit akan meningkatkan kualitas audit, karena rotasi audit secara berkala dapat menjaga independensi auditor, sehingga sulit untuk dipengaruhi atau ditekan oleh pihak manajemen.

Penelitian yang dilakukan Kurniasih (2014) membuktikan bahwa variabel rotasi audit berpengaruh secara signifikan terhadap kualitas audit. Penelitian yang dilakukan oleh Yahya (2015) menunjukan bahwa variabel rotasi audit berpengaruh signifikan terhadap kualitas audit.

Berdasarkan uraian tersebut maka dirumuskan hipotesis kedua : 
$\mathrm{H}_{2}$ : Rotasi audit berpengaruh terhadap kualitas audit.

\section{METODE PENELITIAN}

\subsection{Jenis dan Sumber Data}

Jenis penelitian yang digunakan adalah penelitian kuantitatif. Berdasarkan hubungan antar variabel, maka penelitian ini merupakan penelitian asosiatif, yaitu penelitian yang bertujuan untuk mengetahui hubungan dua variabel atau lebih. Dalam penelitian ini maka akan dapat dibangun suatu teori yang dapat berfungsi untuk menjelaskan, meramalkan dan mengontrol suatu gejala (Sugiyono, 2014). Jadi penelitian ini akan menganalisis pengaruh variabel independen yaitu ukuran perusahaan klien (X1) dan rotasi audit (X2) terhadap variabel dependen yaitu kualitas audit (Y). Sumber data yang digunakan dalam penelitian ini adalah data sekunder yang diambil dari website resmi Bursa Efek Indonesia www.idx.co.id.

\subsection{Sampel dan Teknik Pengambilan Sampel}

Populasi dalam penelitian ini adalah tahun perusahaan manufaktur yang tercatat di Bursa Efek Indonesia (BEI). Sampel yang diambil dari populasi penelitian ini adalah tahun perusahaan manufaktur yang tercatat di Bursa Efek Indonesia (BEI) pada periode tahun 20122015 sebanyak 224 tahun perusahaan manufaktur. Pengambilan sampel dilakukan dilakukan pada periode 2012-2015, karena data laporan keuangan tahunan pada tahun tersebut telah disediakan secara lengkap oleh perusahaan. Teknik pengambilan sampel yang digunakan adalah nonprobability sampling, dengan teknik purposive sampling, yaitu penentuan sampel dari populasi yang ada berdasarkan kriteria. Berdasarkan metode tersebut maka kriteria penentuan sampel yang digunakan dalam penelitian ini adalah sebagai berikut :

1. Perusahaan manufaktur yang terdaftar di Bursa Efek Indonesia (BEI) selama tahun 2012-2015.

2. Perusahaan manufaktur yang menyediakan laporan keuangan secara lengkap dan telah diaudit oleh auditor indenden selama tahun 2012-2015.

3. Perusahaan menerbitkan laporan keuangan dalam mata uang rupiah.

4. Selama penelitian (2012-2015) perusahaan manufaktur tidak mengalami delisting dari Bursa Efek Indonesia (BEI).

\subsection{Metode Analisis}

Metode analisis data yang digunakan dalam penelitian ini adalah analisis regresi logistik (Logistic Regression) dengan bantuan program Statistical Product and Service Solution (SPSS).

\section{HASIL ANALISIS DAN PEMBAHASAN}

\subsection{Hasil Analisis}

\subsubsection{Statistik Deskriptif}

Statistik deskriptif adalah statistik yang digunakan untuk menganalisis data dengan cara mendeskripsikan atau memberikan gambaran data mengenai variabel-variabel penelitian (skeptisme profesional auditor, pengalaman auditor dan kemampuan auditor dalam mendeteksi kecurangan). Hasil statistik deskriptif dapat dilihat pada tabel 4.1 sebagai berikut:

Tabel 4.1 Statistik Deskriptif

\begin{tabular}{|c|c|r|r|r|r|r|r|}
\hline & N & Range & Minimum & Maximum & Sum & Mean & $\begin{array}{c}\text { Std. } \\
\text { Deviation }\end{array}$ \\
\hline $\begin{array}{c}\text { Ukuran } \\
\text { Perusahaan Klien }\end{array}$ & 224 & 7.53 & 11.79 & 19.32 & 3282.23 & 14.6528 & 1.73931 \\
\hline Rotasi Audit & 224 & 1 & 0 & 1 & 20 & .09 & .289 \\
\hline Kualitas Audit & 224 & 1 & 0 & 1 & 101 & .45 & .499 \\
\hline Valid N (listwise) & 224 & & & & & & \\
\hline
\end{tabular}

Sumber : Data olahan SPSS (2018) 
Dari pengujian analisis statistik deskriptif pada tabel 4.2 menunjukan nilai kualitas audit yang diproksikan dengan Kantor Akuntan Publik Big Four atau Non Big Four menggunakan metode variabal dummy memiliki mean sebesar 0,45 dengan nilai minimum 0 dan nilai maksimum 1 yang berarti $45 \%$ dari total 224 laporan keuangan perusahaan diaudit oleh Kantor Akuntan Publik Big Four.

Variabel Ukuran Perusahaan Klien diukur dengan menghitung logaritma natural atas aset perusahaan, dengan nilai minimum sebesar 11,79 yang ditunjukan oleh perusahaan INCI (Intan Wijaya International Tbk) pada tahun 2011 dan nilai maximum sebesar 19.32 yang ditunjukan oleh perusahaan ASII (Astra International Tbk) pada tahun 2015.

Variabel berikutnya adalah rotasi audit diukur dengan variabel dummy, nilai 0 jika tidak ada rotasi auditor dan nilai 1 jika terjadi rotasi auditor. Pada tabel 4.2 variabel rotasi audit dengan nilai sum sebesar 20 yang menunjukan bahwa dari total 224 tahun perusahaan terdapat sebanyak 20 tahun perusahaan menunjukan adanya rotasi audit.

\subsubsection{Uji Hosmer and Lemeshow's Goodness of Fit}

Pengujian kelayakan model regresi logistik dilakukan dengan menggunakan Hosmer and Lemeshow's Goodness of Fit Test yang diukur dengan nilai Chi-Square. Probabilitas signifikansi yang diperoleh kemudian dibandingkan dengan tingkat signifikansi (á) $5 \%$. Hipotesis untuk menilai kelayakan model regresi adalah:

$\mathrm{Ha}$ : Tidak ada perbedaan antara model dengan data

$\mathrm{H} 0$ : Ada perbedaan antara model dengan data

Hasil Uji Hosmer and Lemeshow's Goodness of Fit dapat dilihat pada tabel tabel 4.2 sebagai berikut :

Tabel 4.2 Hasil Hosmer and Lemeshow's Goodness of Fit

\begin{tabular}{|c|c|c|c|}
\hline Step & Chi-square & df & Sig. \\
\hline 1 & 15.428 & 8 & .051 \\
\hline
\end{tabular}

Sumber : Data olahan SPSS(2018)

Tabel 4.2 menunjukkan hasil Hosmer and Lemeshow Test. Hasil pengujian menunjukkan probabilitas signifikan sebesar 0.051. Nilai signifikansi yang diperoleh lebih besar dari $\alpha$ (tingkat signifikansi) 0,05 maka hipotesis a diterima dan hipotesis nol ditolak yang berarti tidak ada perbedaan antara model dengan data.

\subsubsection{Uji Overall Model Fit}

Uji ini digunakan untuk menilai model yang telah dihipotesakan telah fit atau tidak dengan data. Pengujian dilakukan dengan hipotesis :

H0: Model yang dihipotesiskan fit dengan data

Ha: Model yang dihipotesiskan tidak fit dengan data

Pengujian dilakukan dengan membandingkan nilai antara - 2Log Likelihood pada awal (block number $=0)$ dengan nilai -2 Log Likelihood pada akhir (block number $=1)$. Nilai -2 Log Likelihood awal pada block number $=0$, ditunjukkan melalui tabel berikut :

Tabel 4.3

Likelihood Block 0

Iteration History ${ }^{a, b, c}$

\begin{tabular}{|l|r|r|rr|}
\hline \multirow{2}{*}{\multicolumn{2}{|c|}{ Iteration }} & \multirow{2}{*}{ Coefficients } \\
\cline { 4 - 5 } & Step 0 & $\mathbf{- 2}$ Log likelihood & \multicolumn{2}{c|}{ Constant } \\
\cline { 4 - 5 } & 2 & 308.366 & -.196 \\
\hline
\end{tabular}

a. Constant is included in the model.

b. Initial -2 Log Likelihood: 308.366

Sumber : Data olahan SPSS(2018) 
Tabel 4.4 Block Number 1

Iteration History ${ }^{\text {a,b,c,d }}$

\begin{tabular}{|c|c|r|r|r|r|}
\hline \multirow{2}{*}{ Iteration } & \multirow{2}{*}{$\begin{array}{c}-2 \text { Log } \\
\text { likelihood }\end{array}$} & \multicolumn{1}{|c|}{ Coefficients } \\
\cline { 4 - 6 } & & & \multicolumn{1}{c|}{ Constant } & \multicolumn{1}{c|}{ X1 } & \multicolumn{1}{c|}{ X2 } \\
\hline \multirow{3}{*}{ Step 1 } & 1 & 197.820 & -10.974 & .739 & -.634 \\
\cline { 2 - 6 } & 2 & 185.820 & -16.002 & 1.083 & -1.028 \\
\cline { 2 - 6 } & 3 & 184.806 & -17.959 & 1.217 & -1.228 \\
\cline { 2 - 6 } & 4 & 184.794 & -18.203 & 1.234 & -1.260 \\
\cline { 2 - 6 } & 5 & 184.794 & -18.207 & 1.234 & -1.261 \\
\cline { 2 - 6 } & 6 & 184.794 & -18.207 & 1.234 & -1.261 \\
\hline
\end{tabular}

a. Method: Enter

b. Constant is included in the model

c. Initial -2 Log Likelihood: 308.366

d. Estimation terminated at iteration number 6 because parameter estimates changed by less than .001 .

Sumber : Data olahan SPSS(2018)

Tabel 4.3 menunjukkan bahwa $-2 \log \mathrm{L}$ awal pada block number $=0$, yaitu model hanya memasukkan konstanta yang dapat dilihat pada step 2 memperoleh nilai sebesar 308.366. Kemudian pada tabel 4.4 dapat dilihat bahwa setelah masuknya variabel independen pada model nilai -2LogL akhir pada step 6 menunjukkan nilai 184.794. Penurunan nilai -2LogL ini menunjukkan bahwa hipotesis nol diterima atau dengan kata lain model yang dihipotesiskan fit dengan data.

\subsubsection{Uji Koefisien Determinasi (Nagelkerke $R$ Square)}

Koefisien determinasi digunakan untuk mengetahui seberapa besar variabilitas variabel-variabel independen mampu memperjelas variabilitas variabel dependen. Koefisien determinasi pada regresi logistik dapat dilihat pada nilai Nagelkerke $R$ Square. nilai Nagelkerke $R$ Square dapat diinterpretasikan seperti nilai $R$ Square pada regresi berganda (Ghozali, 2006).

Tabel 4.5 Uji Koefisien Determinasi (Nagelkerke $R$ Square) Model Summary

\begin{tabular}{|c|c|c|r|}
\hline & & Cox \& Snell R & Square \\
Step & -2 Log likelihood & Nagelkerke R Square \\
\hline 1 & $184.794^{\mathrm{a}}$ & 0.424 & 0.567 \\
\hline
\end{tabular}

a. Estimation terminated at iteration number 6 because parameter estimates changed by less than .001.

Sumber : Data olahan SPSS(2018)

Tabel 4.5 menunjukkan nilai Nagelkerke R Square. Hasil output pengolahan data, nilai Nagelkerke R Square adalah sebesar 0,567 yang berarti variabilitas variabel dependen yang dapat dijelaskan oleh variabel independen adalah sebesar 56,7\%, sisanya sebesar 43,3\% (100\%-56,7\%) dijelaskan variabilitas variabel-variabel lain di luar model penelitian.

\subsubsection{Uji Hipotesis}

Uji hipotesis dalam penelitian ini dilakukan untuk menguji pengaruh variabel independen yaitu Ukuran Perusahaan Klien dan Rotasi Audit terhadap Kualitas Audit. Metode regresi logistik dapat dilihat dalam tabel berikut : 
Tabel 4.6 Uji Hipotesis

\begin{tabular}{|c|c|r|c|r|r|r|r|r|r|}
\hline & & & & & & & & \multicolumn{2}{|c|}{$\begin{array}{c}\text { 95\% C.I.for } \\
\text { EXP(B) }\end{array}$} \\
\hline & & B & S.E. & Wald & df & Sig. & $\operatorname{Exp}(\mathbf{B})$ & Lower & Upper \\
\hline $\begin{array}{c}\text { Step } \\
\mathbf{1}^{\mathbf{a}}\end{array}$ & $\mathbf{X 1}$ & 1.234 & 0.163 & 57.351 & 1 & 0.000 & 3.436 & 2.497 & 4.730 \\
\hline & $\mathbf{X 2}$ & -1.261 & 0.821 & 2.357 & 1 & 0.125 & 0.283 & 0.057 & 1.418 \\
\hline & Constant & - & 2.388 & 58.128 & 1 & 0.000 & 0.000 & & \\
\hline
\end{tabular}

a. Variable(s) entered on step 1: X1, X2.

Sumber : Data olahan SPSS(2018)

Tabel 4.8 menunjukkan hasil pengujian dengan regresi logistik pada tingkat signifikansi $5 \%$. Dari pengujian dengan regresi logistik di atas maka diperoleh persamaan regresi logistik sebagai berikut ini :

$$
\operatorname{Ln} \frac{p}{1-p}=-18.207(\alpha)+1,234 X 1(U P)-1,261 X 2(R A)
$$

$\begin{array}{lll}\begin{array}{l}\text { Keterangan : } \\ \text { Ln }\end{array} & : \begin{array}{l}\text { Kualitas audit diukur dengan variabel dummy, yaitu kualitas } \\ \text { audit yang dihasilkan dari KAP Big Four yang bernilai = 1, } \\ \text { dan KAP Non Big Four yang bernilai = } 0\end{array} \\ \alpha & : \quad \begin{array}{l}\text { Konstanta } \\ \text { UP }\end{array} & \begin{array}{l}\text { Ukuran perusahaan klien yang dihitung dengan menggunakan } \\ \text { logaritma natural atas total aset perusahaan klien. }\end{array} \\ \text { RA } & : & \begin{array}{l}\text { Rotasi audit diukur dengan variabel dummy yaitu nilai 1 jika } \\ \text { terjadi rotasi auditor, nilai 0 jika tidak terjadi rotasi auditor. }\end{array}\end{array}$

Konstanta sebesar -18,207 bernilai negatif artinya jika variabel ukuran perusahaan klien dan rotasi audit dianggap tidak ada atau sama dengan 0, maka skor kualitas audit akan semakin berkurang. Hasil pengujian hipotesis adalah :

1. $\mathrm{H} 1$ : Hasil Uji Hipotesis menyimpulkan bahwa $\mathrm{Ha}_{1}$ diterima dan $\mathrm{HO}_{1}$ ditolak atau Ukuran Perusahaan Klien berpengaruh secara signifikan terhadap kualitas audit pada perusahaan manufaktur di BEI. Ukuran perusahaan klien pada tabel 4.8 menunjukkan koefisien positif sebesar 1,234 dengan tingkat signifikansi 0,000 yang nilainya berada di bawah tingkat signifikansi 0,05. Ukuran Perusahaan Klien mempengaruhi kualitas audit secara positif pada perusahaan manufaktur di BEI.

2. $\mathrm{H} 2$ : Hasil Uji Hipotesis menyimpulkan bahwa $\mathrm{Ha}_{2}$ ditolak dan $\mathrm{HO}_{2}$ diterima atau Rotasi tidak berpengaruh terhadap kualitas audit pada perusahaan manufaktur di BEI. Ukuran KAP pada tabel 4.8 menunjukkan koefisien negatif sebesar -1,361 dengan tingkat signifikansi 0,125 yang nilainya berada atas tingkat signifikansi 0,05 .

\subsection{Pembahasan}

Hasil pengujian hipotesis pertama menunjukkan, semakin besar ukuran perusahaan klien, maka semakin tinggi pula kualitas audit yang dihasilkan Hasil penelitian ini mendukung penelitian yang dilakukan oleh Sinaga (2014) yang meneliti tentang pengaruh audit tenure, ukuran KAP, dan ukuran perusahaan klien terhadap kualitas audit. Disimpulkan bahwa semakin besar ukuran perusahaan klien maka kualitas audit yang dihasilkan semakin tinggi.

Hasil pengujian hipotesis kedua menunjukkan, rotasi audit tidak berpengaruh terhadap kualitas audit pada perusahaan manufaktur di Bursa Efek Indonesia Periode 2012-2015. Giri (2010) menyatakan bahwa seharusnya ketentuan rotasi auditor mandatory belum diperlukan 
di Indonesia, karena tidak memberikan dampak pada prosedur audit. Penekanan bahwa rotasi wajib auditor akan memberikan manfaat untuk meningkatkan kualitas audit telah mengabaikan masalah penerimaan penugasan awal dan kompleksitas organisasi bisnis modern.

\section{KESIMPULAN DAN SARAN}

\subsection{Kesimpulan}

Berdasarkan hasil penelitian dan pembahasan pada bab sebelumnya, maka disimpulkan bahwa:

5.2.Ukuran perusahaan klien $\left(X_{1}\right)$ berpengaruh secara signifikan terhadap kualitas audit (Y), sehingga $\mathrm{Ha}_{1}$ diterima dan $\mathrm{H}_{1}$ ditolak. Hal ini menunjukkan bahwa semakin besar ukuran perusahaan klien, maka semakin tinggi pula kualitas audit yang di hasilkan.

5.3.Rotasi Audit $\left(\mathrm{X}_{2}\right)$ tidak berpengaruh terhadap kualitas audit $(\mathrm{Y})$, sehingga $\mathrm{H}_{2}$ diterima dan $\mathrm{Ha}_{2}$ ditolak.

\subsection{Saran}

Berdasarkan hasil penelitian dan kesimpulan, maka peneliti memberikan saran:

1. Penelitian berikutnya disarankan menggunakan proksi lain untuk mengukur kualitas audit seperti opini going concern, earning surprise benchmark tingkat discretionary accruals (DA) maupun ukuran lainnya.

2. Bagi peneliti berikutnya diharapkan untuk menambah variabel bebas yang belum digambarkan dalam penelitian seperti audit tenure, fee audit, spesialisasi kantor akuntan publik, maupun variabel lainnya.

3. Memperluas sampel penelitian dengan tidak hanya menguji perusahaan manufaktur, tapi juga di perusahaan lainnya.

\section{DAFTAR PUSTAKA}

Athoi, Muhammad, 2015. "Audit Tenure, Ukuran Kap, Ukuran Perusahaan Klien, dan Spesialisasi Audit Terhadap Kualitas Audit Pada Perusahaan Manufaktur Yang Terdaftar Di Bei". Universitas Sumatera Utara.

Becker et.at. (1998). "The Effect of Audit Quality on Earnings Management". Contemporary Accounting Research, Spring. Vol. 15. pp 1-24.

Bursa Efek Indonesia. 2018. Laporan Keuangan Tahunan. www.idx.co.id.

Febriyanti, Ni Made Dewi dan I Made Mertha. Pengaruh Masa Perikatan Audit, Rotasi KAP, Ukuran Perusahaan Klien, dan Ukuran KAP Pada Kualitas Audit.E-Jurnal Akuntansi Universitas Udayana 7.2(2014):503-518.ISSN: 2302-8556

Fernando, G. D., Ahmed M., dan Randal J. E. 2010. Audit quality attributes, client size and cost of equity capital. "Review of Accounting and Finance, Vol. 9, No. 4, pp. 363-381.

Ghozali, Imam. 2013. Aplikasi Analisis Multivariat dengan Program IBM SPSS 21. Edisi Ketujuh. Universitas Dipenogoro. Semarang.

Giri. Efraim Ferdinan. 2010. Pengaruh Tenure Kantor Akuntan Publik (KAP) dan Reputasi KAP Terhadap Kualitas Audit : Kasus Rotasi Wajib Auditor di Indonesia. Simposium Nasional Akuntansi XIII Purwokerto.

Hartadi, Bambang. (2012). "Pengaruh Fee Audit, Rotasi KAP, dan Reputasi Auditor Terhadap Kualitas Audit di Bursa Efek Indonesia". Jurnal Ekonomi dan Keuangan Volume 16, Nomor 1, Maret $2012: 84-103$.

Kurniasih, Abdul Rohman.2014."Pengaruh Fee Audit, Audit Tenure, dan Rotasi Audit Terhadap Kualitas Audit”.'Diponegoro Journal of Accounting. Vol. 3, No.3, Hal.1-10. 
Maharani. 2014. "Pengaruh Audit Tenure Dan Spesialisasi Auditor Terhadap (Studi Empiris Pada Perusahaan Manufaktur Yang Terdaftar Di Bursa Efek Indonesia Tahun 20112013)'”. Jurnal Mahasiswa Program Studi Akuntansi FEB UMS.

Menteri Keuangan. 2008. Peraturan Menteri Keuangan Republik Indonesia Nomor 17/PMK.01/2008 pasal 3 tentang "Jasa Akuntan Publik". Jakarta.

Sinaga, Daud. (2012). "Analisis Pengaruh Audit Tenure, Ukuran KAP dan Ukuran Perusahaan Klien terhadap Kualitas Audit”. Jurnal publikasi Universitas Diponegoro Semarang.

Sugiyono. 2014. Metode Penelitian Kuantitatif Kualitatif dan R\&D. Alfabeta. Bandung.

Yahya. (2015). "Pengaruh Audit Tenure, Ukuran KAP dan Indepedensi Auditor terhadap Kualitas Audit dengan Fee Audit sebagai Variabel Moderasi pada Perusahaan Manufaktur yang Terdaftar di BEI (2012-2015)". Jurnal Mahasiswa Program Studi Akuntasi FEB UMY. 